\title{
Motivation of University Students Volunteer to Participate in Sportive Activities of Mentally Handicapped Individuals
}

\author{
Oğuz Kaan Esentürk ${ }^{1} \&$ Nuri Berk Güngör ${ }^{2}$ \\ ${ }^{1}$ Physical Education and Sports Teaching Department, Faculty of Education, Erzincan Binali Yıldırım University, \\ Erzincan, Turkey \\ ${ }^{2}$ School of Physical Education and Sport, Karamanoğlu Mehmetbey University, Karaman, Turkey \\ Correspondence: Oğuz Kaan Esentürk, Physical Education and Sports Teaching Department, Faculty of \\ Education, Erzincan Binali Yıldırım University, Erzincan, Turkey.
}

Received: February 18, 2020

Accepted: March 22, 2020

Online Published: June 21, 2020

doi:10.5539/ies.v13n7p95

URL: https://doi.org/10.5539/ies.v13n7p95

\begin{abstract}
The general aim of the study is to determine the motivation of volunteers to participate in the sportive activities of mentally handicapped individuals (Study 1) and to reveal the details that can ensure the continuity of these volunteering activities (Study 2). In Study I, a survey model including the qualitative paradigm was used. Study I was carried out with 138 volunteers who participated in the Special Olympics Turkey event for mentally handicapped individuals in Gazi University. In the study I, an open-ended data collection tool with one question was used to determine the reasons for volunteers to participate in the sportive activities of mentally handicapped individuals. In the study I was used thematic analysis. In study I, It was determined that 121 (Female: 76, Male: 45) volunteers were in the internal motivation sub-dimension, 15 (Female: 4, Male: 11) volunteers were in the external motivation sub-dimension and 2 participants were in the non-motivation sub-dimension. In Study II, it was aimed to examine the expressions of volunteers involved in external motivation and non-motivation dimensions for these dimensions in depth. In Study II, a qualitative research approach was used. Study II was carried out with 17 volunteers involved in the dimensions of External Motivation (n: 15) and Non-motivation among volunteers. In Study II, semi-structured interview form was used as data collection tool. Study II shows the categories and frequencies achieved during interviews with individuals, whose voluntary participation motivations are external motivation and non-motivation. In interviews with volunteers in the external motivation sub-dimension, the following categories were obtained: "Occupational anxiety", "Increasing the Sincerity with Teachers", "Gaining Social Status/Becoming Popular" and "Rewarding Voluntary Participation".
\end{abstract}

Keywords: mentally handicapped individuals, motivation of volunteers, sport, university students

\section{Introduction}

Mental disability is defined as the general mental functions of the individual being under normal and the disability seen in two or more of the adaptive behaviors (American Psychiatric Association [APA], 2013; World Health Organization [WHO], 2012). AAID (The American Association on Intellectual and Developmental Disability) emphasizes that mental disability is not only measured by intelligence testing (IQ) but can also be measured through adaptive behaviors such as academic, social and practical skills (Switzky, Greenspan \& Smith, 2003). Therefore, mental disability brings negative effects on cognitive and social skills as well as mental functions on individuals diagnosed with this disorder.

Mentally handicapped individuals tend to have more health problems than their normally developing peers (Emerson, Glover, Hatton, \& Wolstenholme, 2014; Krahn, Hammond, \& Turner, 2006; Heslop, Blair, Fleming, Hoghton, Marriott, \& Russ, 2014). This trend increases the incidence of obesity, hypertension and cardiovascular health problems among the mentally handicapped individuals in the early stages of life (Lin, Lin, \& Lin, 2010; Wallén, Müllersdorf, Christensson, Malm, Ekblom, \& Marcus, 2009). As a matter of fact, studies show that obesity rates are up to $58 \%$ higher for the mentally handicapped individuals compared to those with normal development and these problems related to obesity and lifestyle affect mentally handicapped people at the alarming rate (Bandini, Curtin, Hamad, Tybor, \& Must, 2005; Slevin et al., 2014).

A physically inactive lifestyle plays an important role in making many health problems more prevalent. In 
addition, it is stated in the literature that there is a high positive relationship between increased physical activity level and healthy lifestyle (Richards, Hillsdon, Thorogood, \& Foster, 2013). However, despite clear findings on the need for an active lifestyle, many studies in the literature show that mentally handicapped individuals have very low levels of participation in physical activity (McGuire, Daly, \& Smyth, 2007; Emerson, 2005; Frey, 2004).

In addition to the contribution of physical activity, sports and exercise to mentally handicapped individuals in terms of having a healthy lifestyle, they have positive effects on other development areas of this population. Research has shown that these practices have positive effects on motor development (Capio, Sit, Eguia, Abernethy, \& Masters, 2014), social skills (Sperstein, 2009; İlhan, 2008), self-respect (Bota, Silvia, \& Şerbănoiu, 2014) and perception of self-efficacy (Mazzoni et al., 2009) of mentally handicapped individuals.

Among the most basic problems of mentally handicapped individuals are the problems of social harmony due to lack of socialization skills. Social harmony is often a challenge for mentally handicapped individuals (Kwekkeboom, De Boer, Van Campen, \& Dorrestein, 2006; Wilken, Medar, Bugarszki, \& Leenders, 2014). They also lack social networks to support them in these matters (Robertson et al., 2001; Verdonschot, de Witte, Reichrath, Buntinx, \& Curfs, 2009; Verplanke \& Duyvendak, 2009). One of the organizations that act as social networks specifically for mentally handicapped individuals is sports organizations. In these organizations, mentally handicapped individuals can benefit from activities that will positively affect all development areas of them. However, volunteerism, which has a direct impact on the conduct of sportive organizations, is an important parameter in achieving such gains.

There are many studies in the literature for volunteers involved in sports organizations (e.g. Bang \& Ross, 2009; Bang, Alexandris, \& Ross, 2008). The selection of volunteers, especially those involved in sportive organizations, is an important part of human resource management processes and is among the most critical criteria for hosting many successful sportive activities (Sharififar, Ganjouie, Tondnevis, \& Zarei, 2011). International Labor Organization (2011) advocates that organizations can be conducted more effectively by proper management of voluntary employees. The fact that around 35,000 volunteers took part in the games in Barcelona in 1992, 50,000 in the 2000 Sydney Olympics (Spa \& Lopez, 2000), 45,000 in the 2004 Athens Games (IOC, 2004) and 70,000 in the 2012 London Olympics (IOC, 2012) emphasized the importance of volunteers for the efficiency of sportive organizations.

In addition, volunteers are very diverse and often represent a variety of nations and cultures, genders, ages, career histories, personal characteristics, and previous volunteering experiences. Such differences are likely to affect the motivation, needs, wishes and behavior of volunteers (Alexander, Kim, \& Kim, 2015). More specifically, when individuals engage in activities, the underlying causes of participation vary between external and internal outcomes. As the external causes of participation become internalized, the causes of participation become compatible with the value perception and goals of the individual and the individual experiences a higher level of participation motivation (Deci \& Ryan, 2000). Therefore, understanding the motivation and personal characteristics of individual volunteers or groups of volunteers can play an active role in determining the most appropriate approaches and strategies for volunteer management.

Considering that the concept of motivation is one of the ideal methods for understanding the decisions of individuals to participate in voluntary activities, determining the motivation sources of sports activity volunteers will help event managers to design more advanced and effective volunteer management strategies according to different needs. Thus, it will be possible to ensure the continuity of qualified volunteers who will take part in sports organizations for mentally handicapped individuals. In addition, no research has been found in which the reasons for volunteer participation in the sportive activities of mentally handicapped individuals were examined according to Self Determination Theory. Therefore, it is foreseen that the findings to be obtained from this research can make important contributions to national and international literature. Also, volunteering courses should be added to the university education curriculum so that university students can continue their voluntary participation in these activities.

In this context, the general aim of the study is to determine the motivation of volunteers to participate in the sportive activities of mentally handicapped individuals (Study 1) and to reveal the details that can ensure the continuity of these volunteering activities (Study 2).

In Study I, the reasons for volunteers' participation in the sportive activities of mentally handicapped individuals were examined according to Self Determination Theory. In Study II, it was aimed to examine the expressions of volunteers involved in external motivation and non-motivation dimensions for these dimensions in depth.

The answer to the following question was sought within the scope of Study I. 
- What is the distribution of volunteers' reasons for participation in sportive activities for mentally handicapped individuals according to the sub-dimensions of Internal Motivation, External Motivation and Non-Motivation?

The answer to the following question was sought within the scope of Study II.

- What are the reasons underlying the opinions of volunteers, whose motivations to participate in the sportive activities for the mentally handicapped individuals are in the dimensions of External Motivation and Non-Motivation?

\section{Method I}

The research was carried out in two stages. In the first stage, the reasons of volunteers to participate in the sportive activities of mentally handicapped individuals were examined according to Self Determination Theory. This part is called "Study I". In the second stage, interviews were conducted with volunteers, whose motivations to participate in the sportive activities for the mentally handicapped individuals are in the dimensions of External Motivation and Non-Motivation. This stage is described as "Study II".

\subsection{Research Model}

In Study I, a survey model including the qualitative paradigm was used. In the survey models, the data to be accessed is collected from the participants and the researcher uses data collection tools such as questionnaires or interview forms to obtain the opinions of the participants (Creswell, 2003). In the study I, a single question form was used to determine the reasons for the voluntary participation of university students in the sportive activities of mentally handicapped individuals.

\subsection{Study Group}

Study I was carried out with 138 volunteers who participated in the Special Olympics Turkey event for mentally handicapped individuals in Gazi University. 82 of the volunteers were female and 56 were male. The average age of volunteers is 21 years. Volunteers are studying in different departments of Gazi University and the majority of them have undergraduate education in the faculty of sports sciences (92\%). In determining the study group, convenient sampling, one of the purposeful sampling methods has been used which is thought to have rich knowledge and allows to study the situations in depth (Yildırım \& Simsek, 2018) and saves time, energy and material resources with quick and easy access to the sample by the researcher.

\subsection{Data Collection Tool}

In the study I, an open-ended data collection tool with one question was used to determine the reasons for volunteers to participate in the sportive activities of mentally handicapped individuals. Whether the question in the data collection tool measures the reasons for participation of volunteers was determined according to expert opinions. Within the scope of expert opinions, 2 academicians were interviewed and the reviewability of the responses obtained with the form according to motivation theory was examined.

\subsection{Data Analysis}

Thematic analysis was used in Study I. This analysis is a type of qualitative data analysis that includes summarizing and interpreting the data obtained by various data collection techniques according to predetermined themes. In this type of research, the researcher may include direct citations in order to reflect conspicuously the opinions of the individuals s/he interviewed or observed. The main purpose of this type of analysis is to present the findings to the reader in a summarized and interpreted form (Yıldırım \& Şimşek, 2018). Volunteers were coded as V1, V2, V3 ... in the study. Deci and Ryan's (1985) Self Determination Theory was taken into consideration in the formation of categories based on volunteer responses.

In Table 1, the dimensions, indicators and functional definitions of Self Determination Theory of Deci \& Ryan (1985) are presented. Indicators and functional definitions presented in Table 1 were used in the analyses. 
Table 1. Dimensions, indicators, functional definitions and sample participant statements of self-determination theory

\begin{tabular}{|c|c|c|c|c|}
\hline \multirow{4}{*}{ 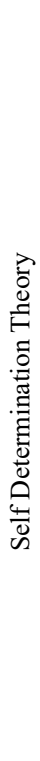 } & Dimensions & Indicators & Functional Definitions & Resource \\
\hline & 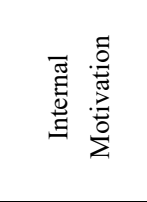 & $\begin{array}{l}\text { As a reason for } \\
\text { participation; pleasure, } \\
\text { satisfaction, } \\
\text { appreciation, } \\
\text { excitement, sincerity }\end{array}$ & $\begin{array}{l}\text { Internal Motivation refers to an individual } \\
\text { taking action to participate in an activity of his } \\
\text { own free will, without anyone or anything. }\end{array}$ & $\begin{array}{l}\text { Cox (1998), Mageau \& } \\
\text { Vallerand (2003), Wann } \\
\text { (1997) }\end{array}$ \\
\hline & 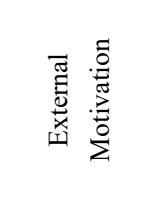 & $\begin{array}{l}\text { As a reason for } \\
\text { participation; external } \\
\text { resources, pressure } \\
\text { from others, reward, } \\
\text { desire to be respected }\end{array}$ & $\begin{array}{l}\text { External Motivation refers to a person } \\
\text { participating in an activity to obtain external } \\
\text { rewards or avoid penalties. }\end{array}$ & $\begin{array}{l}\text { Thøgersen-Ntoumani \& } \\
\text { Ntoumanis (2006), Deci } \\
\text { \& Ryan (1985) }\end{array}$ \\
\hline & 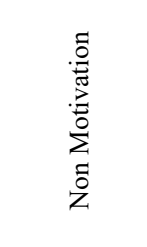 & $\begin{array}{c}\text { As a reason for } \\
\text { participation; cannot } \\
\text { express his/her reasons } \\
\text { for participation in the } \\
\text { activities and } \\
\text { expectations }\end{array}$ & $\begin{array}{l}\text { Non-motivation means that one cannot perceive } \\
\text { the link between his/her behavior and the } \\
\text { consequences of his/her behavior. } \\
\text { They experience a sense of inadequacy and lack } \\
\text { of control. }\end{array}$ & $\begin{array}{l}\text { Pelletier, Fortier, } \\
\text { Vallerand, Tuson, Brière, } \\
\text { \& Blais (1995) }\end{array}$ \\
\hline
\end{tabular}

\section{Results I}

Sub Question: What is the distribution of volunteers' reasons for participation in sportive activities for mentally handicapped individuals according to the sub-dimensions of Internal Motivation, External Motivation and Non-Motivation?

Table 2 shows the distribution of volunteers' reasons for participation in sportive activities for mentally handicapped individuals according to the sub-dimensions of Internal Motivation, External Motivation and Non-Motivation.

Table 2. Distribution of volunteers according to the sub-dimensions of internal motivation, external motivation and non-motivation

\begin{tabular}{|c|c|c|c|c|}
\hline & Sub-dimensions & Participants & Gender (n) & Frequency \\
\hline 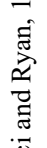 & 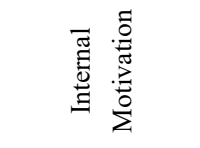 & V1-V29, V33-V37, V41-V86, V91-V110, V114-V120, V122-V127, V132-V138 & $\begin{array}{c}\text { Female (n:76) } \\
\text { Male } \\
(45)\end{array}$ & 121 \\
\hline 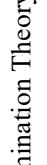 & 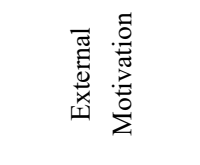 & V30-V32, V38-V40, V87-V88, V112-113, V121, V128-131 & $\begin{array}{c}\text { Female (n:4) } \\
\text { Male (n:11) }\end{array}$ & 15 \\
\hline 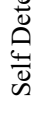 & Z & V90, V111 & $\begin{array}{l}\text { Male } \\
(\mathrm{n}: 2)\end{array}$ & 2 \\
\hline
\end{tabular}

In Table 2, the reasons for volunteers' participation in the sportive activities of mentally handicapped individuals were examined according to Deci and Ryan's (1985) Self Determination Theory. It was determined that 121 (Female: 76, Male: 45) volunteers were in the internal motivation sub-dimension, 15 (Female: 4, Male: 11) volunteers were in the external motivation sub-dimension and 2 participants were in the non-motivation 
sub-dimension.

Among the sample volunteer statements whose reasons for participation were in the internal motivation sub-dimension, the following reasons were observed: Spiritual pleasure, pure love, loving and valuing the people with disabilities, desire to help, that it increases my joy of life, increases my inner peace, because I feel that I am beneficial to people, to make them happy, in order to bring disabled individuals to society, to be able to see the smile in his/her eyes, empathy, because my conscientious feelings predominate, to support all their development.

Among the sample volunteer statements whose reasons for participation were in the external motivation sub-dimension, the following reasons were observed: because it creates a new job opportunity, is a way to prove myself to society, because it will contribute to my resume, to recognize the characteristics of children in this field professionally, to establish more intimate relationships with my teachers.

When examined the sample volunteer statements, whose reasons for participation were in the non-motivation sub-dimension, only two (2) volunteers were found. Among the reasons for the participation of the two volunteers, these two statements were observed: because I wondered what the activities will bring me and and to see if I can acquire professional gain from these activities.

The general purpose of this study is to determine the motivation of volunteers to participate in the sportive activities of mentally handicapped individuals and to determine the details that can provide continuity of these volunteering activities. It is thought that individuals with internal motivation of volunteer participation are highly likely to continue volunteering activities. However, it can be said that individuals, whose volunteer participation motivations are external motivation and non-motivation, are more disadvantaged in terms of participation in activities than individuals with internal motivation. Therefore, a more in-depth study on the reasons for voluntary participation of individuals, whose volunteer participation motivations are external motivation and non-motivation, was considered. In this context, one-to-one interviews were conducted with individuals, whose volunteer participation motivations are external motivation and non-motivation, in Study II. It is foreseen that the data to be obtained can be used to increase the likelihood of individuals, whose volunteer participation motivation are external motivation and non-motivation, to participate in organizations.

\section{Method II}

\subsection{Research Model}

In Study II, a qualitative research approach was used to collect detailed and in-depth data, to directly learn the individual perceptions, experiences and perspectives of the participants, to understand and explain current situations (Büyüköztürk, Kılıç Çakmak, Akgün, Karadeniz, \& Demirel, 2016).

\subsection{Study Group}

Study II was carried out with 17 volunteers involved in the dimensions of External Motivation (n:15) and Non-motivation among volunteers. 13 of the study group were female and 4 were male.

\subsection{Data Collection Tool}

In Study II, semi-structured interview form was used as data collection tool. The interview questions were prepared in a way to provide a more detailed examination of the responses of the participants within the scope of Study I. In other words, through these interview questions, it was aimed to reveal the reasons underlying the opinions of volunteers, whose motivations to participate are in the dimensions of External Motivation (n:15) and Non-Motivation

\subsection{Data Analysis}

Content analysis was used to analyze the data obtained from volunteers within the scope of Study II. Content analysis is performed to reach the concepts and relationships that can explain the collected data. In content analysis, similar data are organized and interpreted under certain concepts and themes in a way that the reader can understand (Yıldırım \& Şimşek, 2018).

\section{Results II}

Sub Questions: What are the reasons that lead volunteers, whose motivations to participate are in the dimensions of External Motivation and Non-Motivation, to this situation? 
Table 3. Categories and frequencies for opinions of volunteers, whose motivations to participate are in the dimensions of external motivation and non-motivation

\begin{tabular}{llll}
\hline Categories (EM) & f & Categories $(\mathrm{N})$ & $\mathrm{f}$ \\
\hline Occupational anxiety & 8 & Possibility of self-improvement & 2 \\
Increasing the sincerity with teachers & 1 & & \\
Gaining social status/becoming popular & 6 & & \\
Rewarding voluntary participation & 2 & & \\
\hline
\end{tabular}

EM: External Motivation, N: Non-motivation, f: Frequency.

Table 3 shows the categories and frequencies achieved during interviews with individuals, whose voluntary participation motivations are external motivation and non-motivation. In interviews with volunteers in the external motivation sub-dimension, the following categories were obtained: "Occupational anxiety", "Increasing the Sincerity with Teachers", "Gaining Social Status/Becoming Popular" and "Rewarding Voluntary Participation". In the following section, voluntary opinions reflecting the raw form of the concepts listed in the above table are presented.

"...the reason I actually participated in these organizations, as I wrote earlier, is not clear whether I will win the exam after school is over and the exam is getting harder and even there is now the major area exam. That's why I chose to participate in these activities that I thought would expand my resume and could offer me new business opportunities...” (V39)

"...I think and know that I am not enough as a branch in school. I can see that the friends chosen for the teams are more popular. I volunteered to participate in disability games because I believed that I could compete with them in this field and introduce myself more at school..." (V121)

“... in the course we had with Teacher Levent (project coordinator), the teacher told us that participation in these organizations would help us to obtain coaching certificate from Turkish Football Federation. My dream of becoming a football coach in the future enabled me to participate in these activities. I can even be a football trainer of mentally handicapped children.” (V88)

"... I saw that the friends who participated in these activities met with the rectors and lecturers. I took this opportunity to show myself to everyone at school." (V30)

In the interviews with volunteers in the non-motivation sub-dimension, the category of "Possibility of self-improvement" was obtained. In the following section, voluntary opinions reflecting the raw form of the concept in the table above as a category are presented.

"... I have never worked with mentally disabled individuals. When I heard about the project, I asked myself if I could improve myself in this area. I said what could happen and I joined in hopes that I could learn something." (V90)

"... the friends who participated in the previous practice said very good things. However, since I didn't know those children, I took risks and participated in the practices without knowing what I would get.” (V11)

\section{Discussion}

In Study I, the reasons for volunteers' participation in the sportive activities of mentally handicapped individuals were examined according to Self Determination Theory. In Study II, it was aimed to examine the expressions of volunteers in external motivation and non-motivation dimensions in depth.

Within the scope of Study I, the reasons for volunteers' participation in the sportive activities of mentally handicapped individuals were examined according to Self Determination Theory and the motivation of volunteers to participate was determined to be largely internal motivation $(88 \%)$. When the indicators of internal motivation are taken into consideration, it is thought that feelings such as pleasure, satisfaction, pleasure, excitement and sincerity are thought to be the reasons behind the participation of volunteers with participation motivation in this dimension. In a study (Kim, Zhang, \& Connaughton, 2010), it was determined that the participation motivation of volunteers participating in activities for children with special needs was in the dimension of "value". In the same study, it was found that there was a significant difference between the volunteers in the "value" dimension in favor of female. There is consistency between the present study and the two results mentioned above. In the literature, the findings obtained in the studies on voluntary participation motivation (Clary et al., 1998; Allison, Okun \& Dutridge, 2002; Caldwell \& Andereck, 1994; Williams, Dossa, \& Tompkins, 1995; Eley \& Kirk, 2002) are thought to be in line with the findings of the present study. 
Within the scope of Study II, it was provided to investigate in depth the reasons underlying these expressions of the volunteers in the dimensions of external motivation and non-motivation. Within the scope of interviews with individuals, whose voluntary participation motivations are external motivation and non-motivation, the following categories were obtained from the volunteers involved in external motivation sub-dimension: "Occupational anxiety", "Increasing the Sincerity with Teachers", "Gaining Social Status/Becoming Popular" and "Rewarding Voluntary Participation". In the interviews with volunteers in the non-motivation sub-dimension, the category of "Possibility of self-improvement" was obtained. Numerous studies (Cuskelly et al., 2006; Kim \& Chelladurai, 2008; MacLean \& Hamm, 2007) showed that volunteer motivation plays an important role for individuals who do not have financial expectations, receive in-service training, spend time and effort and remain in a voluntary position. In addition, Clary et al. (1998) state that the concept of motivation is behind the reasons, goals, plans and objectives that enable people to initiate, direct and maintain voluntary actions. Therefore, it is thought that volunteers in the internal motivation dimension are highly likely to continue volunteering activities. However, since the concept of motivation is the driving force, various regulations may be needed to sustain the voluntary participation of individuals with different sources of motivation (external motivation and non-motivation). In addition, after volunteers are selected, organizations should provide prudent appropriate support and create an atmosphere that meets the motivational needs of volunteers during the activity (Kim, Zhang, \& Connaughton, 2010). Studies show that an individual's satisfaction with voluntary participation is directly proportional to the level of meeting the motivational needs of that individual (McClelland, 1961; Murray, 1938). Kim et al. (2009) stated that if volunteer expectations are not met, volunteers are less motivated and less likely to stay in the organization. Therefore, continuity of volunteering activities can be ensured by the necessary arrangements for volunteers whose participation motivations are not in the internal motivation dimension.

\section{References}

Allison, L. D., Okun, M. A., \& Dutridge, K. S. (2002). Assessing volunteer motives: a comparison of an open-ended probe and Likert rating scales. Journal of Community \& Applied Social Psychology, 12(4), 243-255. https://doi.org/10.1002/casp.677

APA (American Psychiatric Association). (2013). Diagnostic and statistical manual of mental disorders (5th ed.). Arlington, VA: Author. https://doi.org/10.1176/appi.books.9780890425596

Bandini, L. G., Curtin, C., Hamad, C., Tybor, D. J., \& Must, A. (2005). Prevalence of overweight in children with developmental disorders in the continuous National Health and Nutrition Examination Survey (NHANES) 1999-2002. Journal of Pediatrics, 146, 738-743. https://doi.org/10.1016/j.jpeds.2005.01.049

Bang, H., \& Ross, S. D. (2009). Volunteer motivation and satisfaction. Journal of Venue and Event Management, $1(1), 61-77$.

Bang, H., Alexandris, K., \& Ross, S. D. (2008). Validation of the revised volunteer motivations scale for international sporting events (VMS-ISE) at the Athens 2004 Olympic Games. Event Management, 12(3-4), 119-131. https://doi.org/10.3727/152599509789659759

Bota, A., Silvia, T., \& Şerbănoiu, S. (2014). Unified Sports - A social inclusion factor in school communities for young people with intellectual disabilities. Procedia-Social and Behavioral Sciences, 117, 21-26. https://doi.org/10.1016/j.sbspro.2014.02.172

Büyüköztürk, Ş., Kılıç Çakmak E., Akgün, Ö. E., Karadeniz, Ş., \& Demirel, F. (2016). Bilimsel araştırma yöntemleri (20. Bask1). Ankara: Pegem A Yayınc1lık. https://doi.org/10.14527/9789944919289

Caldwell, L. L., \& Andereck, K. L. (1994). Motives for initiating and continuing membership in a $\begin{array}{lllll}\text { recreation-related voluntary association. Leisure } & \text { Sciences, } & \text { 16(1), }\end{array}$ https://doi.org/10.1080/01490409409513215

Capio, C. M., Sit, C. H., Eguia, K. F., Abernethy, B., \& Masters, R. (2014). Fundamental movement skills training to promote physical activity in children with and without disability: A pilot study. Journal of Sport and Health Science, 4(3), 235-243. https://doi.org/10.1016/j.jshs.2014.08.001

Clary, E. G., Snyder, M., Ridge, R. D., Copeland, J., Stukas, A. A., \& Haugen, J., (1998). Understanding and assessing the motivations of volunteers: A functional approach. Journal of Personality and Social Psychology, 74(6), 1516-1530. https://doi.org/10.1037/0022-3514.74.6.1516

Cox, R. H. (1998). Sport psychology: concepts and applications (4th ed.). The McGraw-Hill.

Creswell, J. W. (2003). Research design: Qualitative, quantitative and mixed methods approaches. California: Sage Publication. 
Curran, T., Hill, A. P., \& Niemiec, C. P. (2013). A conditional process model of children's behavioralengagement and behavioral disaffection in sport based on self-determination theory. Journal of Sport and Exercise Psychology, 35(1), 30-43. https://doi.org/10.1123/jsep.35.1.30

Curran, T., Hill, A. P., Hall, H. K., \& Jowett, G. E. (2014). Perceived coach behaviors and athletes' engagement and disaffection in youth sport: The mediating role of the psychological needs. International Journal of Sport Psychology, 45(6), 559-580. Retrieved from http://eprints.glos.ac.uk/id/eprint/3829

Cuskelly, G., Taylor, T., Hoye, R., \& Darcy, S. (2006). Volunteer management practices and volunteer retention: A human resource management approach. Sport Management Review, 9, 141-163. https://doi.org/10.1016/S1441-3523(06)70023-7

Deci, E. L., \& Ryan, R. M. (1985). Intrinsic motivation and self-determination in human behavior. New York, NY: Plenum Press. https://doi.org/10.1007/978-1-4899-2271-7

Deci, E. L., \& Ryan, R. M. (2000). The "what" and "why" of goal pursuits: Human needs and the self determination of behavior. Psychological Inquiry, 11(4), 227-268. https://doi.org/10.1207/S15327965PLI1104_01

Eley, D., \& Kirk, D. (2002). Developing citizenship through sport: The impact of a sport-based volunteer programme on young sport leaders. Sport, Education, and Society, 7(2), 151-166. https://doi.org/10.1080/1357332022000018841

Emerson, E. (2005). Underweight, obesity and exercise among adults with intellectual disabilities in supported accommodation in Northern England. Journal of Intellectual Disability Research, 49(2), 134-143. https://doi.org/10.1111/j.1365-2788.2004.00617.x

Emerson, E., Glover, G., Hatton, C., \& Wolstenholme, J. (2014). Trends in age-standardised mortality rates and life expectancy of people with learning disabilities in Sheffield over a 33-year period. Tizard Learning Disability Review, 19(2), 90-95. https://doi.org/10.1108/TLDR-01-2014-0003

Frey, G. C. (2004). Comparison of physical activity levels between adults with and without mental retardation. Journal of Physical Activity and Health, 1(3), 235-245. https://doi.org/10.1123/jpah.1.3.235

Heslop, P., Blair, P. S., Fleming, P., Hoghton, M., Marriott, A., \& Russ, L. (2014). The Confidential Inquiry into premature deaths of people with intellectual disabilities in the UK: A population-based study. The Lancet, 383(9920), 889-895. https://doi.org/10.1016/S0140-6736(13)62026-7

İlhan, L. (2008). Eğitilebilir Zihinsel engelli çocuklarda beden eğitimi ve sporun sosyalleşme düzeyine etkisi. Kastamonu Eğitim Dergisi, 16(1), 315-324. Retrieved from https://s3.amazonaws.com/academia.edu.documents/39711639

International Labor Organization. (2011). Manual on the Measurement of Volunteer Work (Geneva).

IOC. (2004). More about Athens 2004. Retrieved from http://olympic.org/athens2004-summer-olympics

IOC. (2012). Volunteers: Helping to make the Game happens. Retrieved from $\mathrm{http}: / /$ olympic.org/news/volunteers-helping-to make-the-game-happen-168630

Kim, M., \& Chelladurai, P. (2008). Volunteer preferences for training influences of individuals difference factors. International Journal of Sport Management, 9(3), 233-249.

Kim, M., Zhang, J. J., \& Connaughton, D. P. (2010). Comparison of volunteer motivations in different youth sport organizations. European Sport Management Quarterly, 10(3), 343-365. https://doi.org/10.1080/16184741003770198

Krahn, G. L., Hammond, L., \& Turner, A. (2006). A cascade of disparities: Health and health care access for people with intellectual disabilities. Mental Retardation and Developmental Disabilities Research Reviews, 1, 70-82. https://doi.org/10.1002/mrdd.20098

Kwekkeboom, M., De Boer, A., Van Campen, C., \& Dorrestein, A. (2006). Een eigen huis... Ervaringen van mensen met verstandelijke beperkingen of psychiatrische problemen met zelfstandig wonen en deelname aan de samenleving. Den Haag: Sociaal en Cultureel Planbureau.

Lin, P. Y., Lin, L. P., \& Lin, J. D. (2010). Hypertension, hyperglycemia, and hyperlipemia amongadolescents with intellectual disabilities. Research in Developmental Disabilities, 31(2), 545-550. https://doi.org/10.1016/j.ridd.2009.12.002

Mageau, G. A., Vallerand, R. J. (2003). The coach-athlete relationship: A motivational model. Journal of Sports 
Sciences, 21, 883-904. https://doi.org/10.1080/0264041031000140374

Mazzoni, E. R., Purves, P. L., Southward, J., Rhodes, R. E., \& Temple, V. A. (2009). Effect of indoor wall climbing on self-efficacy and self-perceptions of children with special needs. Adapted Physical Activity Quarterly, 26(3), 259-273. https://doi.org/10.1123/apaq.26.3.259

McClelland, D. C. (1961). The achieving society. New York: Van Nostrand. https://doi.org/10.1037/14359-000

McGuire, B. E., Daly, P., \& Smyth, F. (2007). Lifestyle and health behaviours of adults with anintellectual disability. Journal of Intellectual Disability Research, 51(7), 497-510. https://doi.org/10.1111/j.1365-2788.2006.00915.x

Murray, H. (1938). Exploration and personality. New York, NY: Oxford University Press.

Pelletier, L. G., Fortier, M. S., Vallerand, R. J., Tuson, K. M., Brière, N. M., \& Blais, M. R. (1995). Toward a new measure of intrinsic motivation, extrinsic motivation, and a motivation in sport: The sport motivation scale (SMS). Journal of Sport \& Exercise Psychology, 17(2), 35-53. https://doi.org/10.1123/jsep.17.1.35

Richards, J., Hillsdon, M., Thorogood, M., \& Foster, C. (2013). Face-to-face interventions for promoting physical activity. Cochrane Database of Systematic Reviews, 9. https://doi.org/10.1002/14651858.CD010392

Robertson, J., Emerson, E., Gregory, N., Hatton, C., Kessissoglou, S., Hallam, A., \& Linehan, C. (2001). Social networks of people with mental retardation in residential settings. Mental Retardation, 39(3), 201-214. https://doi.org/10.1352/0047-6765(2001)039<0201:SNOPWM>2.0.CO;2

Sharififar, F., Ganjouie, F. A., Tondnevis, F., \& Zarei, A. (2011). Effect of social factors and motives on commitment of sport events volunteers. Technics Technologies Education Management-Ttem, 6(1), 184-190.

Slevin, E., Truesdale-Kennedy, M., McConkey, R., Livingstone, B., \& Fleming, P. (2014). Obesity and overweight in intellectual and non-intellectually disabled children. Journal of Intellectual Disability Research, 58, 211-220. https://doi.org/10.1111/j.1365-2788.2012.01615.x

Spa, M. D. M., \& Lopez, B. (2000). Decentralization processes and "proximate television" in Europe. Routledge Research In Cultural and Media Studies, 7, 33-51.

Switzky, N., S. Greenspan, R. S., \& Smith, D. (2003). What is mental retardation? Washington, DC: AAMR Books and Research Monographs Editor.

Thøgersen-Ntoumani, C., \& Ntoumanis, N. (2006). The role of selfdetermined motivation in the understanding of exercise-related behaviours, cognitions and physical self-evaluations. Journal of Sports Sciences, 24(4), 393-404. https://doi.org/10.1080/02640410500131670

Verdonschot, M. M. L., de Witte, L. P., Reichrath, E., Buntinx, W. H. E., \& Curfs, L. M. G. (2009). Community participation of people with an intellectual disability: A review of empirical findings. Journal of Intellectual Disability Research, 53, 303-318. https://doi.org/10.1111/j.1365-2788.2008.01144.x

Verplanke, L., \& Duyvendak, J. (2009). Eenzaam maar o zo autonoom: Over het thuisgevoel van zelfstandig wonende mensen met psychiatrische of verstandelijke beperkingen. Sociologie, 5, 300-315. Retrieved from https://hdl.handle.net/11245/1.311117

Wallén, E. F., Müllersdorf, M., Christensson, K., Malm, G., Ekblom, Ö., \& Marcus, C. (2009). High prevalence of cardio-metabolic risk factors among adolescents with intellectual disability. Acta Paediatrica, 98(5), 853-859. https://doi.org/10.1111/j.1651-2227.2008.01197.x

Wann, D. L. (1997). Sport psychology. Upper Saddle River, New Jersey: Pretice-Hall.

Wilken, J.-P., Medar, M., Bugarszki, Z., \& Leenders, F. (2014). Community support and participation among persons with disabilities. A study in three European countries. Journal of Social Intervention: Theory and Practice, 23(3), 44-59. https://doi.org/10.18352/jsi.410

Williams, P. W., Dossa, K. A., \& Tompkins, L. (1995). Volunteerism and special event management: A case study of Whistler's Men's World Cup of Skiing. Festival Management \& Event Tourism, 3, 83-95.

World Health Organization (WHO). (2012). Definition: Intellectual Disabilities. Retrieved from http://www.euro.who.int/en/what-we-do/health-topics/noncommunicablediseases/mentalhealth/news/news/2 010/15/childrens-right-to-family-life/definition-intellectualdisability

Yıldırım, A., \& Şimşek, H. (2018). Sosyal bilimlerde nitel araştırma yöntemleri (11. Baskı). Ankara: Seçkin 
Basımevi.

\section{Copyrights}

Copyright for this article is retained by the author(s), with first publication rights granted to the journal.

This is an open-access article distributed under the terms and conditions of the Creative Commons Attribution license (http://creativecommons.org/licenses/by/4.0/). 